\title{
Multicenter investigation of predictors to self-report vaccination and seroprotection against Hepatitis B among healthcare workers
}

Investigação multicêntrica dos preditores de autorelato de vacinação e soroproteção contra Hepatite $B$ entre profissionais de saúde

Investigación multicéntrica de predictores de autoinformación de vacunación y seroprotección contra la hepatitis $B$ entre profesionales de la salud

Vivianne Lins Ebrahim MORCERF ${ }^{1}$

Celina Maria Costa LACET $^{2}$

Álvaro LARGURA ${ }^{3}$

Evanio da SILVA ${ }^{3}$

Kevan Guilherme Nóbrega BARBOSA ${ }^{1}$

Sonia Maria Soares FERREIRA ${ }^{\mathbf{1}}$

Silvio Romero de Oliveira ABREU ${ }^{1}$

${ }^{1}$ Mestrado Profissional Pesquisa em Saúde, Centro Universitário Cesmac, 57051-530, Maceió-AL, Brasil

${ }^{2}$ Departamento de Gastroenterologia e Hepatologia, UNCISAL Universidade de Ciências da Saúde, 57010-300, Maceió-AL, Brasil

${ }^{3}$ Laboratório Biovel, 85801-090, Cascavel-PR, Brasil

\begin{abstract}
Objective: The Healthcare Workers (HCWs) are professionals with occupational exposure risk to Hepatitis B virus (HBV). Vaccination status has been widely explored; however, few investigations had confirmed the HBV immunity by serological test. Method: We performed a multicenter study based on a dual approach to understand the predictive factors of vaccination and seroprotection to HBV among HCWs. A cross-section design investigation was carried out among 371 workers from Alagoas state (Brazil); all of them from the public health service. Multiple Poisson Regression Models were constructed using vaccination and seroprotection as dependent factor. Results: The overall self-report of vaccination was $70.4 \%$ and the confirmation by immune response was $72.2 \%$. Three predictive factors were associated with vaccination: education level; use of the PPE during work, and personal serological evaluation. Two predictive factors were associated with seroprotection: education level and use of the PPE during work. Conclusion: Our findings showed some evidence that almost one third of healthcare workers were not immune to HBV, and factors such as education and use of the protective equipment can predict the susceptibility to HBV.
\end{abstract}

Descriptors: Hepatitis B; Vaccination; Immunization; Health Personnel.

\section{Resumo}

Objetivo: Os profissionais de saúde trabalham com exposição à riscos ocupacionais para o Vírus da Hepatite $\mathrm{B}$ (VHB). O status de vacinação tem sido amplamente explorado; entretanto, poucas investigações têm confirmado a imunidade ao VHB por teste sorológico. Material e Método: Realizamos um estudo multicêntrico baseado em uma abordagem dupla para entender os fatores preditores de vacinação e soroproteção ao VHB entre profissionais de saúde. Um estudo de corte seccional foi delineado entre 371 trabalhadores do estado de Alagoas (Brasil); todos eles do serviço público de saúde. Construímos um Modelo Múltiplo de Regressão de Poisson utilizando a vacinação e a soroproteção como fatores dependentes. Resultados: O total de auto relato de vacinação foi de $70,4 \%$ e a confirmação pela resposta imune foi de $72,2 \%$. Três preditores estiveram associados com vacinação: nível educacional; uso de equipamento de proteção individual durante o trabalho e avaliação sorológica individual. Dois preditores estiveram associados com soroproteção: nível educacional e uso de equipamento de proteção durante o trabalho. Conclusão: Nossos achados apontaram que quase um terço dos profissionais de saúde não estavam imunizados para o VHB, e traz alguma evidencia que fatores como educação e uso de equipamento de proteção individual podem predizer a susceptibilidade para VHB.

Descritores: Hepatite B; Vacinação; Imunização; Pessoal de Saúde.

\section{Resumen}

Objetivo: Los profesionales de la salud trabajan con exposición a riesgos laborales por el virus de la hepatitis B (VHB). El estado de vacunación se ha explorado ampliamente; sin embargo, pocas investigaciones han confirmado la inmunidad al VHB mediante pruebas serológicas. Material y método: Realizamos un estudio multicéntrico basado en un enfoque dual para comprender los predictores de la vacunación contra el VHB y la seroprotección entre los profesionales de la salud. Se diseñó un estudio transversal entre 371 trabajadores del estado de Alagoas (Brasil); todos ellos del servicio de salud pública. Construimos un modelo de regresión de Poisson múltiple utilizando la vacunación y la seroprotección como factores dependientes. Resultados: La vacunación autoinformada total fue del 70,4\% y la confirmación por respuesta inmune fue del $72,2 \%$. Tres predictores se asociaron con la vacunación: nivel educativo; uso de equipo de protección personal durante el trabajo y evaluación serológica individual. Dos predictores se asociaron a la seroprotección: nivel educativo y uso de equipo de protección durante el trabajo. Conclusión: Nuestros hallazgos señalaron que casi un tercio de los profesionales de la salud no estaban inmunizados contra el VHB, y aporta alguna evidencia de que factores como la educación y el uso de equipo de protección personal pueden predecir la susceptibilidad al VHB.

Descriptores: Hepatitis B; Vacunación; Immunización; Personal de Salud.

\section{INTRODUCTION}

Hepatitis B virus (HBV) is a well recognized bloodborne virus ${ }^{1}$ member of the hepadnaviridae family ${ }^{2}$ which transmission occurs through parenteral, sexual and vertical means, being able to be active in infected individuals ${ }^{3}$. Immunity to HBV is defined by anti$\mathrm{HBc}$, and anti-HBs serological markers, and when at least one of them is reagent, the individual is considered immune (nonsusceptible $)^{4,5}$. Chronic infection is responsible for several liver disorders including cirrhosis, hepatocellular carcinoma, liver failure and other hepatic diseases ${ }^{1,3,6,7}$.

HBV infection is widely spread and about one third of the world population is infected, and more than 350 million individuals have the chronic form of the disease ${ }^{8,9}$, corresponding to a global major problem due to its high morbidity and mortality ${ }^{10}$. Annually, over 4 million new acute cases are reported ${ }^{6}$ and 
600,000 deaths are related to $\mathrm{HBV}^{11,12}$. Healthcare Workers (HCWs) are a population at high risk for occupational disease including HBV infection, mainly because they are frequently exposed to blood and body fluids $2,3,13-15$.

HBV prevention through passive (seroprotection) or active immunization is the best way to prevent HBV-related diseases, its effectiveness is high, about $90-95 \%$, and it was estimated in 2011 that the global vaccination prevalence for the third dose was $78 \%{ }^{16}$ Since 1998, the Brazilian National Immunization Program recommended vaccination against HBV at birth and for groups at risk such as health professionals. ${ }^{17}$ In 2002, the Brazilian government, through the National Program of Viral Hepatitis, implemented a series of actions to encourage hepatitis prevention, including the participation of $\mathrm{HCW}^{18,19}$.

Previous investigations had been focused on the vaccination status of HCWs at different locations, which is obviously important; however, this information is based on professional self-report, which could be biased. In addition, surveillance agencies recommend immunization certification with serological tests $^{20}$, which should attest antibody against the surface antigen - anti-HBS ${ }^{21}$. To overcome this limitation, the seroprotection status of HCWs calibrated via serological tests was included in our analysis. The objective of the present investigation was to determine the vaccination and seroprotection prevalence against HBV among health care workers and to investigate the predictive factors related to HBV, to provide a better understanding on the situation among healthcare workers in two cities located in northeastern Brazil (developing country).

MATERIAL AND METHOD

\section{- Study Design and Setting}

An exploratory cross-sectional study was carried out to investigate factors that could be associated with vaccination and seroprotection against Hepatitis $B$ among public health workers of two major cities in the state of Alagoas, northeastern Brazil. The investigation period occurred between October 2016 and January 2017. Alagoas is a small state, comprising an area of $27,848.140 \mathrm{~km}^{2}$, with estimated population of $3,322.820$ inhabitants in $2018 .^{22}$ Maceió is the state capital and largest city, followed by Arapiraca (128 km away from the state capital).

According to Government data, in 20162017, Alagoas had the following Public Health Units located in Maceió/Arapiraca: five 24h emergency services; 2 emergency hospitals; 2 hematology/hemotherapy services; 1 center of pharmaceutical assistance; 1 pediatric clinic; and several mobile emergency services. ${ }^{23}$

○ Participants

The eligibility criteria included health workers enrolled in the framework of active staffs of Secretaria de Estado da Saúde de Alagoas (SESAU), working in the Public Health Units of the state and in risk to occupational infection by HBV. The reason why we chose only the professionals from the public service is due to the importance and the great number of users attended by this kind of service, consequently in risk to cross-infection. The SESAU is the largest health institution in the state.

The following Public Health Units were included: five $24 \mathrm{~h}$ emergency services; 2 emergency hospitals; 2 hematology/hemotherapy services; 1 pediatric clinic and data from several mobile emergency services. To select participants to be included in the study, a list with all health workers' names was obtained, with a number being attributed to each of them. Based on a probabilistic selection, the first number was chosen, and after that, the selection continued with no reposition until minimum sample size was obtained (explained in the "study size" topic). This step was accomplished in the Excel software using the 'function' tool. A priori, we had no exclusion criterion, only in the statistical analysis phase; considering the multiple regression, we excluded the missing data.

\section{- Predictive Factors and Data Measurement}

Primary outcomes (dependent variables) were self-reported vaccination prevalence and HBV seroprotection prevalence. HBV vaccination was defined as the self-reported administration of 3 or more doses. Seroprotection status was defined by anti-HBs and total anti-HBc serologic tests. The recommendations of the Center for Disease Control and Prevention - CDC to consider the immunity status were followed: anti-HBs $\geqq 10$ $\mathrm{mlU} / \mathrm{ml}$ (reagent); and anti-HBc reagent (recovered from past infection) or non-reagent (passive immunization) ${ }^{1}$. We coded " 0 " as selfreported vaccination and " 1 " as no self-reported vaccination; and after the lab test we included a new value of seroprotection, and we coded " 0 " to protected status (seroprotection) and " 1 " to susceptible status.

In order to explain the variability in the vaccination/seroprotection status among health workers, some explanatory variables were included to predict the outcomes. Three major groups of predictive factors were used: 1 sociodemographic conditions (sex, age, 
education level, monthly income, marital status); 2 - work conditions (occupation, health unit, years as health worker); and 3 - prevention (institutional serological evaluation, personal serological evaluation, training in worker's health, use of personal protective equipmentPPE during work, work accident with biological material, frequency of work accident). "Institutional serological evaluation" refers whether the professionals have already been tested for HBV during his/her job in the public service, while "personal serological evaluation" is related to private test. "Training in worker's health" refers whether the professional had any training or continuing education about hepatitis $B$ and "use of personal protective equipmentPPE" refers whether the professionals protected themselves during the work.

\section{- Study Size}

The study population during the recruitment phase was 3664 health workers from the public service network. Minimum representative sample was achieved with the expected prevalence of $65 \%$ of vaccination prevalence based on previous research ${ }^{24,25}$. Sample size for finite population was calculated using the following formula:

$$
n_{a d j}=\frac{N \times\left[1,96^{2} \times P_{\exp }\left(1-P_{\exp }\right) / d^{2}\right]}{N+\left[1,96^{2} \times P_{\text {exp }}\left(1-P_{\text {exp }}\right) / d^{2}\right]}
$$

$\mathrm{n}_{\text {adj }}=$ adjusted sample size; $\mathrm{N}=$ population; $1,96=$ population standard deviation; $\mathrm{P}_{\exp }=$ expected prevalence; $\mathrm{d}=$ error $(0,05)$

Using the equation above, minimum sample for our primary outcome was 318 participants. The final size considered $17 \%$ of non-response rate, and returned 371 fully evaluation.

\section{- Data Acquisition}

Two different data were used. Firstly, data related to quantitative variables were collected, including sociodemographic conditions, work conditions, and prevention. A structured questionnaire was coded as "0" (no), "1" (yes), or coded according to the type of variable; e.g.: sex ("0" male and " 1 " female); education level ("0" elementary school, " 1 " high school, and "2" higher education). To obtain all the information, a research member of the team was trained to make the initial recruitment of health workers. In the first contact, the researcher explained the aims of the study and obtained the signed authorization of workers after reading the consent form. When the participant accepted to participate, the researcher led the volunteer to a private room to accomplish the questionnaire application.

The second phase was performed after the step aforementioned; the workers were accompanied to the lab of his own place of work to initiate the blood collection. All samples were forwarded to the Campus of one University Center to centrifugation and subsequent freezing of the extracted sera. After 100-stored sample, we sent the material via air transportation to a specialized lab in clinical analysis to obtain the results of the serological tests for seroprotection against HBV.

\section{- Statistical Methods}

To compare the agreement between vaccination and seroprotection status, the Kappa test was used, considering values varying between 0 and 1 (0-none; <0.2-poor; 0.21 to 0.40 -reasonable; 0.41 to 0.60 -moderate; 0.61-0.80-good; 0.81-0.99-excellent; 1-perfect).

The primary outcome was a binary categorical variable expressed as percentage; "self-report vaccinated" or "self-report not vaccinated" for vaccination status and "immune" or "susceptible" for seroprotection status. All predictive variables were categorical and assumed percentage values. First, bivariate analysis was applied using the Poisson Regression to estimate the unadjusted Prevalence Ratio (PR) in a "one-to-one" crossing. Then, multiple analysis was applied to observe the interaction of several variables through an iterative process in the statistical software.

The initial step was the inclusion of all variables with $p$-value less than 0.25 in the binary comparison, than we observed what happened with each factor into the model. For each outcome, many models were constructed and the one that best adjusted the test of model effects was chosen. We consider the adjust of Hosmer-Lemeshow test and the absence of outliers in the final model. First, we observed the adjust of the model without the factors, later we observed how was the goodness of fit after include all factors in the model. The interpretation of the Hosmer-Lemeshow test is better when the null hypothesis $\left(\mathrm{H}_{0}\right)$ is confirmed, and the predicted-values in the model are statically equal to the observedvalues.

\section{- Ethics Approval}

All bioethics principles were followed during recruitment and data collection. The National recommendations of the Brazilian Health Council in its resolution 466/12 were followed, which provides a guideline for research involving human beings; and the International guide of the Declaration of Helsinki. Before the beginning of the study, the research project was registered in the "Plataforma Brasil" (Brazilian base of all human researches) and approved by an independent Research Ethics Committee, 
obtaining register number CAAE 54289316.8.0000.0039.

\section{RESULTS}

We bring results from $371 \mathrm{HCWs}$, and this number was achieved based on sample calculation estimated to 318 professionals and we added 53 participants considering the possible losses. The overall self-reported vaccination prevalence among the 371 health workers was $70.4 \%$ (261) and the seroprotection prevalence confirmed by the serological test was $72.2 \%$ (268). In the self-reported vaccination, small portion of workers that did not remember $(8.6 \% ; \mathrm{n}=32)$ and did not want to answer $(2.1 \% ; n=8)$ was observed. For seroprotection; $25.6 \%(95)$ of health workers were susceptible and $2.2 \%$ (8) were in the acute phase of HBV. Figure 1 display the flowchart including the number and percentage of vaccination and seroprotection status according to the sample, respectively.

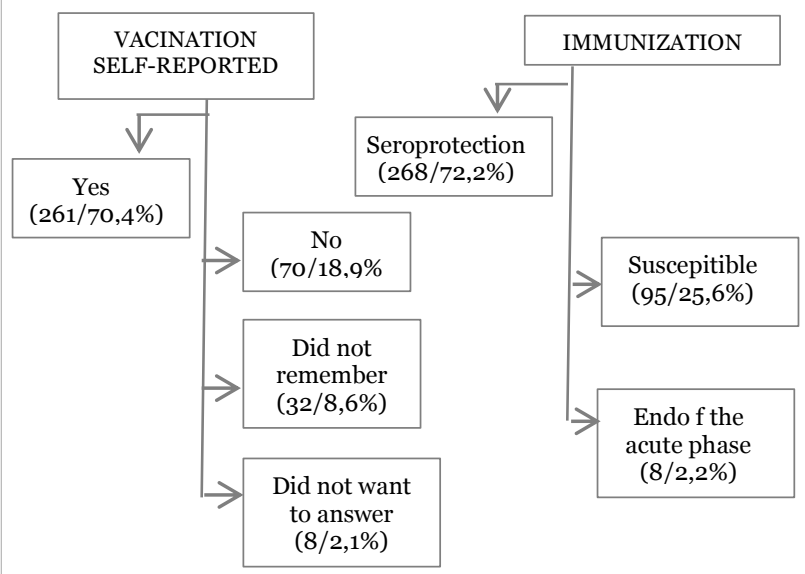

Figure 1: Flowchart including the number and percentage of vaccination and seroprotection status.

Of the 261 who confirm had taken 3 or more doses, 197 were in fact immune and among the non-vaccinated 46 were immune. The agreement between self-report of vaccination and seroprotection status was $8.4 \%$ (poor agreement; Kappa $=0.084, p=0.128$ ). The bivariate analysis is presented in tables 1 and 2 , respectively. It was observed that five factors were significant for vaccination, but only two considered seroprotection.

After the modeling process for vaccination status, the third model had the best fit and was adjusted to educational level; use of PPE during work, and personal serological evaluation, as can be observed in table 3. PR for elementary school and high school compared to higher education in susceptible workers according to self-reported vaccination were 3.64 (Cl 95\%: 1.75-7.55) and 1.86 (Cl 95\%1.18-2.92) respectively. Health workers that reported no personal serological evaluation were $4.27(\mathrm{Cl}$
95\%: 1.38-13.1) times more likely of presenting the worst condition (susceptibility to Hepatitis B) and workers that reported no PPE use were 2.91 (Cl 95\%: 1.86-4.53) times more likely of presenting the worst condition.

The seroprotection status showed the true serological pattern for susceptibility to Hepatitis B. The final model (third) was adjusted for two predictive factors: educational level and use of PPE during work. PR for elementary school compared to higher education in susceptible workers according to immunity was 2.02 (Cl 95\%: 1.08-3.75). The lack of PPE use during work was reported 1.63 times more among workers susceptible to Hepatitis $\mathrm{B}(\mathrm{Cl}$ 95\%: 1.04-2.57). Table 4 shows the Poisson regression results and all three models constructed.

Table 1. Vaccination status to Hepatitis B of the health workers assessed by the self-report

\begin{tabular}{|c|c|c|c|c|c|}
\hline \multicolumn{6}{|c|}{ Vaccination Self-Reported to Hepatitis B* } \\
\hline & Yes & No & $\boldsymbol{\beta}$ & $\begin{array}{l}\text { PR }_{\text {unadjusted }} \\
\text { (CI-95\%) }\end{array}$ & $\boldsymbol{p}$ \\
\hline \multicolumn{6}{|l|}{$\operatorname{Sex}$} \\
\hline female & $57(19,9 \%)$ & $229(80,1 \%)$ & & 1 & \\
\hline male & $13(28,9 \%)$ & $32(71,1 \%)$ & 0,37 & $1,45(0,79-2,64)$ & 0,22 \\
\hline \multicolumn{6}{|l|}{ Age } \\
\hline quartile 1 (26-39 years) & $14(19,2 \%)$ & $59(80,8 \%)$ & & 1 & \\
\hline $\begin{array}{l}\text { quartile } 2 \\
\text { (40-48 years) }\end{array}$ & $10(13,2 \%)$ & $66(86,8 \%)$ & $-0,37$ & $0,68(0,30-1,54)$ & 0,36 \\
\hline quartile 3 ( $49-56$ years) & $10(15,4 \%)$ & $55(84,6 \%)$ & $-0,22$ & $0,80(0,35-1,80)$ & 0,59 \\
\hline $\begin{array}{l}\text { quartile } 4 \\
(57-68 \text { years })\end{array}$ & $26(37,7 \%)$ & $43(62,3 \%)$ & 0,67 & $1,96(1,02-3,76)$ & 0,04 \\
\hline \multicolumn{6}{|l|}{ Marital Status } \\
\hline with partner & $42(19,9 \%)$ & $169(80,1 \%)$ & & 1 & \\
\hline no partner & $22(20,6 \%)$ & $85(79,4 \%)$ & 0,03 & $1,03(0,61-1,73)$ & 0,90 \\
\hline \multicolumn{6}{|l|}{ Education Level } \\
\hline fundamental (9 years) & $5(35,7 \%)$ & $9(64,3 \%)$ & 0,96 & $2,63(1,00-6,90)$ & 0,04 \\
\hline medium (12 years) & $38(29,2 \%)$ & $92(70,8 \%)$ & 0,76 & $2,15(1,29-3,59)$ & 0,003 \\
\hline higher $(>12$ yeas $)$ & $24(13,6 \%)$ & $153(86,4 \%)$ & & 1 & \\
\hline \multicolumn{6}{|l|}{ Income } \\
\hline 1-5 minimum wages & $44(21,7 \%)$ & $159(78,3 \%)$ & 0,50 & $1,66(0,51-5,35)$ & 0,39 \\
\hline 6-9 minimum wages & $10(21,3 \%)$ & $37(78,7 \%)$ & \multirow[t]{2}{*}{0,48} & $1,63(0,45-5,92)$ & \multirow[t]{2}{*}{0,45} \\
\hline$\geq 10$ minimum wages & $3(13,0 \%)$ & $20(87,0 \%)$ & & 1 & \\
\hline \multicolumn{6}{|l|}{ Health Unit } \\
\hline emergency service 1 & $4(11,1 \%)$ & $32(88,9 \%)$ & & 1 & \\
\hline emergency service 2 & $3(33,3 \%)$ & $6(66,7 \%)$ & 1,09 & $3,00(0,67-13,4)$ & 0,15 \\
\hline emergency service 3 & $7(38,9 \%)$ & $11(61,1 \%)$ & 1,25 & $3,50(1,02-11,9)$ & 0,04 \\
\hline emergency service 4 & $2(15,4 \%)$ & $11(84,6 \%)$ & 0,32 & $1,38(0,25-7,55)$ & 0,70 \\
\hline emergency service 5 & $3(30,0 \%)$ & $7(70,0 \%)$ & 0,99 & $2,70(0,60-12,0)$ & 0,19 \\
\hline emergency hospital 1 & $15(19,7 \%)$ & $6180,3 \%)$ & 0,57 & $1,77(0,59-5,35)$ & 0,30 \\
\hline emergency hospital 2 & $16(19,5 \%)$ & $66(80,5 \%)$ & 0,56 & $1,75(0,58-5,25)$ & 0,31 \\
\hline hematology service 1 & $2(12,5 \%)$ & $1487,5 \%)$ & 0,11 & $1,12(0,20-6,14)$ & 0,89 \\
\hline hematology service 2 & $3(18,8 \%)$ & $13(81,2 \%)$ & 0,52 & $1,68(0,37-7,54)$ & 0,49 \\
\hline $\begin{array}{l}\text { mobile emergency } \\
\text { service }\end{array}$ & $5(14,3 \%)$ & $30(85,7 \%)$ & 0,25 & $1,28(0,34-4,78)$ & 0,70 \\
\hline pediatric clinic & $10(50,0 \%)$ & $10(50,0 \%)$ & 1,50 & $4,50(1,44-14,3)$ & 0,01 \\
\hline \multicolumn{6}{|l|}{ Profession } \\
\hline nurse & $4(6,9 \%)$ & $54(93,1 \%)$ & & 1 & \\
\hline nursing assistant & $15(25,9 \%)$ & $43(74,1 \%)$ & & $3,75(1,24-11,3)$ & 0,01 \\
\hline nursing technician & $30(24,0 \%)$ & $95(76,0 \%)$ & & $3,48(1,22-9,87)$ & 0,01 \\
\hline social worker & $4(25,0 \%)$ & $12(75,0 \%)$ & & $3,62(0,90-14,4)$ & 0,06 \\
\hline technical staff & $6(46,2 \%)$ & $7(53,8 \%)$ & & $6,69(1,88-23,7)$ & 0,003 \\
\hline other & $11(18,0 \%)$ & $50(82,0 \%)$ & & $2,61(0,83-8,21)$ & 0,10 \\
\hline \multicolumn{6}{|c|}{ Years as Health Worker } \\
\hline up to 4 years & $2(10,5 \%)$ & $17(89,5 \%)$ & & 1 & \\
\hline $5-9$ years & $7(28,0 \%)$ & $18(72,0 \%)$ & 0,97 & $2,66(0,55-12,8)$ & 0,22 \\
\hline$\geq 10$ years & $61(21,3 \%)$ & $226(78,7 \%)$ & 0,70 & $2,01(0,49-8,25)$ & 0,32 \\
\hline \multicolumn{6}{|c|}{ Institutional Serological Evaluation? } \\
\hline yes & $7(10,0 \%)$ & $63(90,0 \%)$ & & 1 & \\
\hline no & $61(24,6 \%)$ & $187(75,4 \%)$ & 0,90 & $2,46(1,12-5,37)$ & 0,02 \\
\hline \multicolumn{6}{|c|}{ Personal Serological Evaluation? } \\
\hline yes & $3(4,4 \%)$ & $65(95,6 \%)$ & & 1 & \\
\hline no & $65(25,9 \%)$ & $186(74,1 \%)$ & 1,77 & $5,87(1,84-18,6)$ & 0,003 \\
\hline \multicolumn{6}{|c|}{ Training in Worker's Health? } \\
\hline yes & $31(19,6 \%)$ & $127(80,4 \%)$ & & 1 & \\
\hline & $34(21,7 \%)$ & $123(78,3 \%)$ & 0,09 & $1,10(0,67-1,79)$ & 0,69 \\
\hline Use of the PPE during & work? & & & & \\
\hline yes & $50(17,3 \%)$ & $239(82,7 \%)$ & & 1 & \\
\hline no & $18(48,6 \%)$ & $19(51,4 \%)$ & 0,27 & $2,81(1,64-4,81)$ & $<0,001$ \\
\hline Work Accident with $\mathrm{E}$ & ological $M c$ & erial? & & & \\
\hline yes & $24(15,2 \%)$ & $134(84,8 \%)$ & & 1 & \\
\hline no & $42(25,0 \%)$ & $126(75,0 \%)$ & 0,49 & $1,64(0,99-2,71)$ & 0,05 \\
\hline Frequency of Work A & ident? & & & & \\
\hline never & $42(25,0 \%)$ & $126(75,0 \%)$ & & 1 & \\
\hline 1 & $10(13,3 \%)$ & $65(86,7 \%)$ & $-0,62$ & $0,53(0,26-1,06)$ & 0,07 \\
\hline 2 & $5(11,4 \%)$ & $39(88,6 \%)$ & $-0,78$ & $0,45(0,18-1,14)$ & 0,09 \\
\hline 3 or more & $9(23,7 \%)$ & $29(76,3 \%)$ & $-0,05$ & $0,94(0,46-1,94)$ & 0,88 \\
\hline
\end{tabular}


Table 2. Immunization status to Hepatitis B of the health workers confirmed by the serological test

\begin{tabular}{|c|c|c|c|c|c|}
\hline \multicolumn{6}{|c|}{ Immunization status to Hepatitis $\mathrm{B}^{*}$} \\
\hline & Susceptible & Immune & $\boldsymbol{\beta}$ & $\begin{array}{c}\text { PR }_{\text {unadjusted }} \\
\text { (CI-95\%) }\end{array}$ & $\boldsymbol{p}$ \\
\hline \multicolumn{6}{|l|}{ Sex } \\
\hline female & $79(25,2 \%)$ & $234(74,8 \%)$ & & 1 & \\
\hline male & $16(32,0 \%)$ & $34(68,0 \%)$ & 0,23 & $1,26(0,81-1,98)$ & 0,29 \\
\hline \multicolumn{6}{|l|}{ Age } \\
\hline quartile 1 (26-39 years) & $7(21,5 \%)$ & $62(78,5 \%)$ & & 1 & \\
\hline $\begin{array}{l}\text { quartile } 2 \\
\text { (40-48 years) }\end{array}$ & $23(27,1 \%)$ & $62(72,9 \%)$ & 0,22 & $1,25(0,72-2,17)$ & 0,41 \\
\hline quartile 3 (49-56 years) & $18(25,0 \%)$ & $54(75,0 \%)$ & 0,15 & $1,16(0,65-2,07)$ & 0,61 \\
\hline $\begin{array}{l}\text { quartile } 4 \\
\text { (57-68 years) }\end{array}$ & $23(30,3 \%)$ & $53(69,7 \%)$ & 0,34 & $1,40(0,81-2,41)$ & 0,21 \\
\hline \multicolumn{6}{|l|}{ Marital Status } \\
\hline with partner & $66(28,9 \%)$ & $162(71,1 \%)$ & 0,26 & $1,30(0,88-1,93)$ & 0,17 \\
\hline no partner & $27(22,1)$ & $95(77,9 \%)$ & & 1 & \\
\hline \multicolumn{6}{|l|}{ Education Level } \\
\hline fundamental (9 years) & $8(47,1 \%)$ & $9(52,9 \%)$ & 0,69 & $2,00(1,13-3,52)$ & 0,01 \\
\hline medium (12 years) & $41(27,5 \%)$ & $108(72,5 \%)$ & 0,15 & $1,16(0,81-1,68)$ & 0,40 \\
\hline higher ( $>12$ yeas) & $44(23,5 \%)$ & $143(76,5 \%)$ & & & \\
\hline \multicolumn{6}{|l|}{ Income } \\
\hline & & $4,4 \%)$ & & 1 & \\
\hline & & & 0,10 & & 0,70 \\
\hline & & & 0,18 & 3) & 0,55 \\
\hline \multicolumn{6}{|l|}{ Health Unit } \\
\hline emergency service 1 & & $31(77,5 \%)$ & 1,32 & $3,750,55-25,2)$ & 0,17 \\
\hline emergency service 2 & $1(11,1 \%)$ & $8(88,9 \%)$ & & & \\
\hline emergency service 3 & $4(20,0 \%)$ & $16(80,0 \%)$ & 0,97 & $2,64(0,36-19,3)$ & 0,33 \\
\hline emergency service 4 & $5(38,5 \%)$ & $8(61,5 \%)$ & 0,98 & $2,45(0,30-19,7)$ & 0,39 \\
\hline emergen & $3(27,3$ & $8(72$ & 0,83 & $2,30(0,33-15,7)$ & 0,39 \\
\hline emergen & $20(22$, & 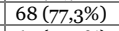 & 1,24 & $3,46(0,48-$ & 0,21 \\
\hline emergency hospit & $23(26,7 \%)$ & $63(73$ & 0,70 & $2,02(0,29-1$ & 0,47 \\
\hline hematology service 1 & $5(29,4 \%)$ & & 1,03 & $2,81(0,38-2$ & 0,30 \\
\hline hematology service 2 & & $11(68)$ & 0,71 & $2,04(0,31$ & 0,45 \\
\hline $\begin{array}{l}\text { mobile } \\
\text { service }\end{array}$ & $10(25,6 \%)$ & $29(74,4 \%)$ & 0,87 & $2,40(0,36-15,7)$ & 0,36 \\
\hline pediatric clinic & & & 1,50 & & 0,57 \\
\hline \multicolumn{6}{|l|}{ Profession } \\
\hline nurse & & & 0,26 & $1,30(0,52-3,27)$ & 0,56 \\
\hline & & & 0,23 & $1,27(0,74$ & 0,38 \\
\hline & & & & & \\
\hline & & & 0,69 & $2,01(0,93-4$ & 0,07 \\
\hline technical staff & & & 0,71 & $2,04(1,3$ & 0,002 \\
\hline other & $16(27$ & & 0,35 & $1,41(0,8$ & 0,20 \\
\hline \multicolumn{6}{|c|}{ Years as Health Worker } \\
\hline up to 4 years & $4(2$ & & & & \\
\hline & & & & & 0,32 \\
\hline \multirow{2}{*}{\multicolumn{6}{|c|}{ Institutional Serological Evaluation? }} \\
\hline & & & & & \\
\hline yes & & & & 1 & 0 \\
\hline \multirow{2}{*}{\multicolumn{6}{|c|}{ Personal Serological Evaluation? }} \\
\hline & & & & & \\
\hline yes & $15(21,7 \%)$ & $54(78$ & & 1 & \\
\hline no & $76(27,0 \%)$ & $205(73,0 \%)$ & 0,21 & $1,24(0,76-2,02)$ & 0,37 \\
\hline \multicolumn{6}{|c|}{ Training in Worker's Health? } \\
\hline yes & & & 0,06 & $1,07\left(0,75^{-1}\right.$ & 0,70 \\
\hline \multirow{2}{*}{\multicolumn{6}{|c|}{ Use of the PPE during work? }} \\
\hline & & & & & \\
\hline yes & $78(24,6 \%)$ & & & 1 & \\
\hline no & $15(37,5 \%)$ & $25(62,5 \%)$ & 0,22 & $1,5^{2}(0,97-2,37)$ & 0,06 \\
\hline \multicolumn{6}{|c|}{ Biological } \\
\hline yes & & & & & \\
\hline & $55(28,9 \%)$ & & 0,25 & $1,28(0,9$ & 0,16 \\
\hline Frequency of Work & ccident? & & & & \\
\hline never & $55(28,9 \%)$ & & & 1 & \\
\hline 1 & $20(24,7 \%)$ & & $-0,1$ & $0,85(0,54-$ & 0,47 \\
\hline 2 & $7(15,2 \%)$ & $39(84$ & $-0,64$ & $0,52(0,25-1,07)$ & 0,07 \\
\hline 3 or more & $11(26,2 \%)$ & $31(73,8 \%)$ & $-0,10$ & $0,90(0,52-1,57)$ & 0,72 \\
\hline
\end{tabular}

\section{DISCUSSION}

We present in this paper not only the vaccination status of healthcare workers, as this information could be affected by the memory bias. In addition, the seroprotection status of these workers was also investigated to best characterize susceptibility to HBV. By using regression models, the prevalence of each predictive factor was estimated according to the primary outcome, and some possible factors that might be associated with seroprotection in HCWs were elucidated. The discussion will focus on the significant results after adjusting factors in the final model.
HBV seroprotection confirmed by the serological test was observed in a frequency of seven in ten, which is a good number considering other national ${ }^{24,26,27}$ and international investigations $\mathrm{s}^{6-8,13,27}$, in which the prevalence was lower, ranging from 52 to $64 \%$ and from 12 to $67 \%$, respectively. Higher vaccination prevalence was observed in Southeastern Brazil $^{3,28}$ and Lybia ${ }^{15}$. Although immunization was higher than in the above studies, the goal of the Brazilian Ministry of Health in 2014 was the vaccination of $95 \%$ of the population against $\mathrm{HBV}^{29}$.

Table 3. Regression Poisson models with the adjusted prevalence ratio for the vaccination self-report to Hepatitis $B$

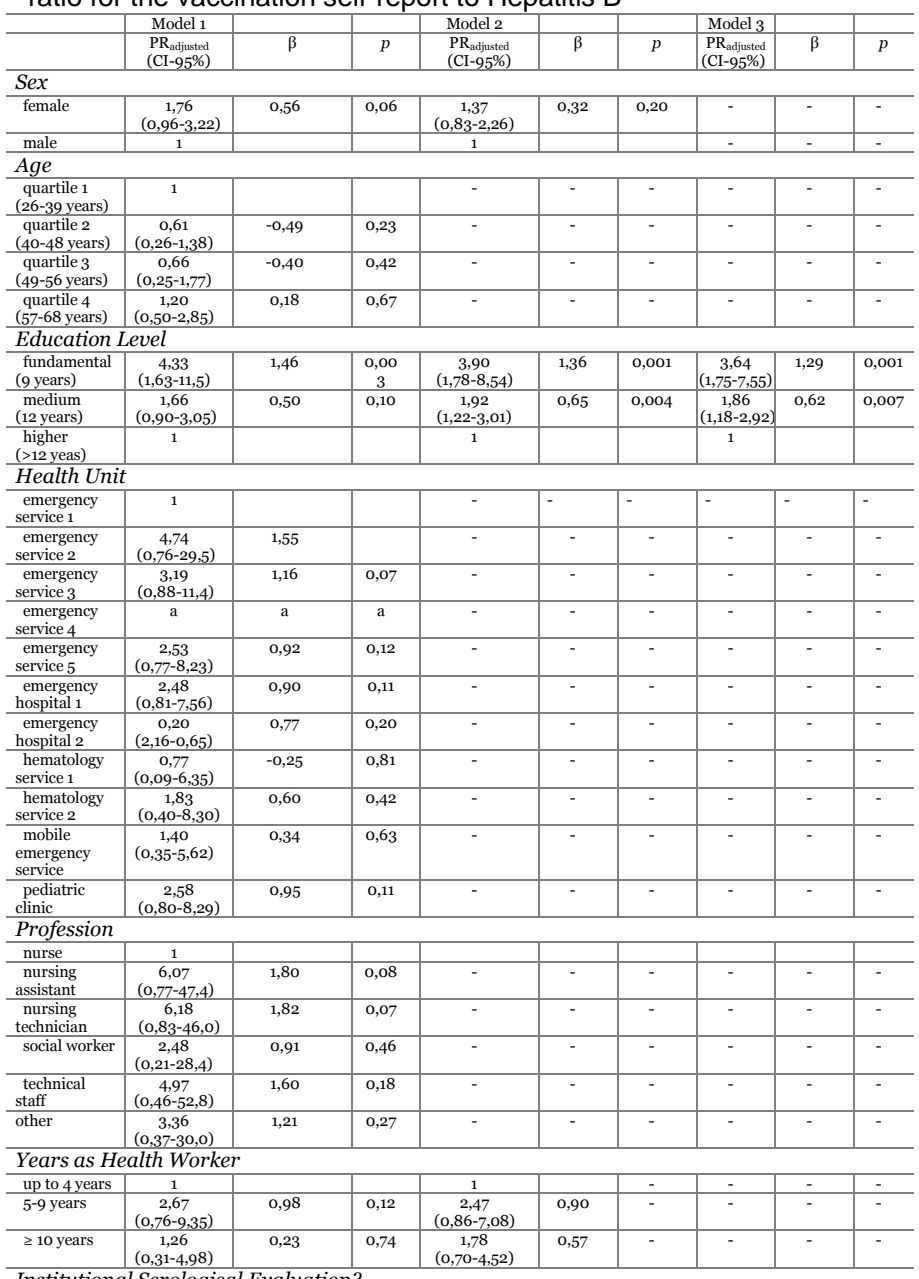

Institutional Serological Evaluation?

\begin{tabular}{l|c|c|c|c|c|c|c|c|c}
\hline yes & 1,51 \\
\hline no & $(0,70-3,29)$ & 0,41 & 0,28 & - & - & - & - & - & - \\
\hline
\end{tabular}

Personal Serological Evaluation?

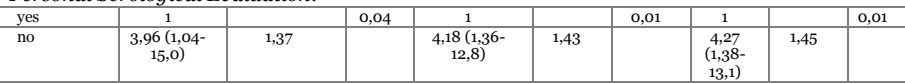

Use of the PPE during work?

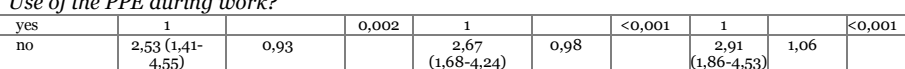

Work Accident with Biological Material?

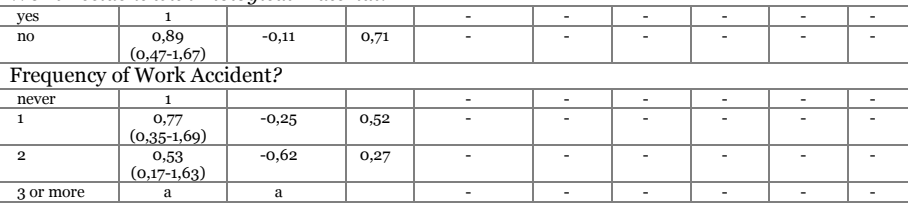

a: not calculated as the test requirement were not satisfied. 
Table 4. Regression Poisson models with the adjusted prevalence ratio for the immunization status to Hepatitis $\mathrm{B}$, confirmed by serological test

\begin{tabular}{|c|c|c|c|c|c|c|c|c|c|}
\hline & Model 1 & & & Model 2 & & & Model 3 & & \\
\hline & 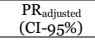 & $\beta$ & $p$ & 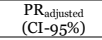 & $\beta$ & $p$ & 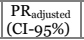 & $\beta$ & $p$ \\
\hline \multicolumn{10}{|l|}{ Age } \\
\hline $\begin{array}{l}\text { पuartile } 1 \\
(26-39 \text { years })\end{array}$ & 1 & & & - & - & - & - & - & \\
\hline $\begin{array}{l}\text { quartile } 2 \\
(40-48 \text { years })\end{array}$ & $\begin{array}{l}1,16 \\
(0,64-2,11)\end{array}$ & 0,13 & 0,65 & - & - & - & - & - & - \\
\hline $\begin{array}{l}\text { quartile } 3 \\
\text { (49-56 bears) }\end{array}$ & $\begin{array}{c}0,87 \\
(0,42-181)\end{array}$ & $-0,15$ & 0,66 & - & - & - & - & - & \\
\hline 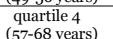 & $\begin{array}{l}0,1,25 \\
(0.63-245)\end{array}$ & 0,15 & 0,65 & - & - & - & - & - & - \\
\hline \multicolumn{10}{|c|}{$\begin{array}{l}(15-68 \text { years })(0,63-2,45) \\
\text { Eduction Level }\end{array}$} \\
\hline $\begin{array}{l}\text { fundamental } \\
\text { (9 years) }\end{array}$ & $\begin{array}{c}2,30 \\
(1,07-4,93)\end{array}$ & 0,71 & 0,07 & 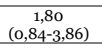 & 0,59 & 0,12 & \begin{tabular}{|c|c|}
2,02 \\
$(1,08-3,75)$ \\
\end{tabular} & 0,70 & 0,02 \\
\hline $\begin{array}{l}\text { medium } \\
(12 \text { years })\end{array}$ & $\begin{array}{l}1,1,9 \\
(0,78-2,14)\end{array}$ & 0,28 & 0,26 & $\left(\begin{array}{c}1,27 \\
(0,80-2,03)\end{array}\right.$ & 0,24 & 0,30 & $(0,8,8-1,73)$ & 0,18 & 0,31 \\
\hline 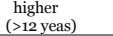 & & & & & & & & & \\
\hline \multicolumn{10}{|c|}{ Health Unit } \\
\hline 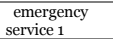 & $\begin{array}{c}1,59 \\
(0,211,8)\end{array}$ & 0,46 & 0,64 & - & & & & & \\
\hline $\begin{array}{l}\text { emergency } \\
\text { service }\end{array}$ & 1 & & & & & & & & \\
\hline $\begin{array}{l}\begin{array}{l}\text { emergency } \\
\text { service } 3\end{array} \\
\text { a }\end{array}$ & $\begin{array}{c}1,27 \\
(0,1-1-10,2)\end{array}$ & 0,24 & 0,81 & - & - & - & - & - & - \\
\hline $\begin{array}{l}\text { emergency } \\
\text { service } 4\end{array}$ & $\begin{array}{c}0,54 \\
(0,03-8,83)\end{array}$ & $-0,60$ & 0,67 & - & - & - & - & - & \\
\hline $\begin{array}{l}\text { emergency } \\
\text { semvice } 5\end{array}$ & 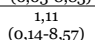 & 0,10 & 0,91 & - & - & - & - & - & - \\
\hline $\begin{array}{l}\text { emergency } \\
\text { hosital } 1\end{array}$ & 1,11 & 0,10 & 0,92 & - & - & - & - & - & - \\
\hline $\begin{array}{l}\text { hospital } 1 \text { er } \\
\text { emergency }\end{array}$ & $\begin{array}{l}(0,13-, 949) \\
1,09\end{array}$ & 0,08 & 0,93 & - & - & - & - & - & \\
\hline $\begin{array}{l}\text { hospstal } 2 \\
\text { hematology }\end{array}$ & $\frac{(0,14-8,83)}{1,17}$ & 0,15 & 0,88 & $-r_{2}$ & - & - & - & - & - \\
\hline $\begin{array}{l}\text { service } 1 \\
\text { hematology }\end{array}$ & $(0,13-10,2)$ & & & & & & & & \\
\hline $\begin{array}{l}\text { hematology } \\
\text { service } 2\end{array}$ & $\begin{array}{c}1,24 \\
(0,17-8,91)\end{array}$ & 0,22 & 0,82 & - & - & & - & - & - \\
\hline $\begin{array}{l}\text { mobile } \\
\text { emergency } \\
\text { service }\end{array}$ & $\begin{array}{c}1,40 \\
(0,19-10,0)\end{array}$ & 0,33 & 0,73 & - & - & - & - & - & - \\
\hline $\begin{array}{l}\text { pediatric } \\
\text { clinic }\end{array}$ & $\begin{array}{c}0,91 \\
(0,12-6,97)\end{array}$ & $-0,08$ & 0,93 & - & - & - & - & - & - \\
\hline \multicolumn{10}{|l|}{ Profession } \\
\hline nurse & $\begin{array}{c}1,38 \\
(0,53-3,61)\end{array}$ & 0,32 & 0,50 & $\begin{array}{c}1,47 \\
(0,59-3,67)\end{array}$ & 0,38 & 0,40 & - & - & - \\
\hline 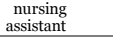 & $\begin{array}{c}1,06 \\
(0,56-2,02)\end{array}$ & 0,06 & 0,83 & $\begin{array}{c}1,28 \\
0.7-2,23)\end{array}$ & 0,24 & 0,37 & - & - & - \\
\hline $\begin{array}{l}\text { nursing } \\
\text { technician }\end{array}$ & 1 & & & 1 & & & & & \\
\hline social worker & $\begin{array}{c}1,69 \\
(0,79-3,60)\end{array}$ & 0,52 & 0,17 & $\begin{array}{c}1,98 \\
(0,90-4,35)\end{array}$ & 0,68 & 0,08 & - & - & - \\
\hline $\begin{array}{l}\text { technical } \\
\text { staff }\end{array}$ & $\begin{array}{l}1,64 \\
(0,94-2,85)\end{array}$ & 0,49 & 0,07 & $\begin{array}{c}1,90,80 \\
1,180 \\
(1,12-2,91\end{array}$ & 0,59 & 0,01 & - & - & \\
\hline other & $\begin{array}{ll}1,38 \\
(0,65-2,1)\end{array}$ & 0,32 & 0,39 & $\begin{array}{c}1,61 \\
(0.86-300)\end{array}$ & 0,47 & 0,13 & - & - & - \\
\hline \multicolumn{10}{|c|}{ Use of the PPE during work? } \\
\hline yes & & 0,62 & 0,02 & $\frac{1}{1,53}$ & 0,42 & 0,07 & \begin{tabular}{|c|}
1 \\
1,63
\end{tabular} & & 0.03 \\
\hline & $\begin{array}{l}1,07-3,25) \\
(1,07\end{array}$ & & & $(0,96-2,44)$ & & & $|(1,04-2,577)|$ & 0,49 & \\
\hline \multicolumn{10}{|c|}{ Work Accident with Biological Material? } \\
\hline yes & $\left(0,45^{-1,82}\right)$ & $-0,09$ & 0,76 & & & & & & \\
\hline \multicolumn{10}{|c|}{$\begin{array}{l}\text { no } \\
\text { Frequency of Work Accident? }\end{array}$} \\
\hline $\begin{array}{ll}\text { never } \\
1\end{array}$ & & & & - & - & - & - & - & - \\
\hline & $\begin{array}{c}0,90 \\
(0,45-1,82)\end{array}$ & $-0,10$ & 0,77 & & & & & & \\
\hline 2 & $\begin{array}{c}0,45 \\
(0,16-1,24)\end{array}$ & $-0,79$ & 0,12 & - & - & - & - & - & \\
\hline & $\mathrm{a}$ & & & - & - & - & - & - & - \\
\hline
\end{tabular}

The increase in vaccination prevalence and consequently the decrease of HBV infection in many countries result from the expansion of immunization programs ${ }^{28}$. In Brazil, since the end of 1990's, the government implemented the immunization program against HBV for infants and children in the northern region; however, only in 1992, the vaccination of risk groups expanded to other regions ${ }^{10}$. In the year of 2012 , the Ministry of Health included the immunization to the population aged 19-29 years ${ }^{3}$.

An interesting result of the present study was the poor agreement between self-reported vaccination and seroprotection; however, the prevalence between them was not divergent, which means that many answers "no" to vaccination status actually represent "yes" and vice versa. These results show that we should be careful in use only self-reported vaccination to investigate predictive factors. In order to avoid this bias, the real seroprotection prevalence among HCWs was introduced by using concomitantly two serological markers: anti-HBc and anti-HBs.
Educational status was clearly associated in the multiple analysis regression for both; vaccination and seroprotection, which means that HCWs with lower educational level were more susceptible to HBV compared to those with higher schooling. Previous investigation has found that the higher the educational level, the higher the protection of health workers against HBV via vaccination $^{3,24,26,30}$. Pereira et al. $^{10}$ in a multicenter analysis for three Brazilian regions showed that only in the Northeastern region, the low educational level is a risk factor for HBV considering the general population, but no analysis was performed regarding HCWs.

Souza et al. ${ }^{10}$ explain that the association between schooling and low protection against HBV among health workers reinforces the inequity among different health categories. Although higher educational level has usually been positively associated with protection against HBV among HCWs, an unexpected result was found in the southern Brazil; professionals with medium or lower education had better vaccination prevalence against HBV. Our survey was conducted in northeastern Brazil, in the state of Alagoas, which is considered one of the most deprived areas in Brazil, including low quality of education and other social deprivation, representing a major challenge. It was hypothesized that improving education could bring several indirect benefits, including better vaccination prevalence, as individuals become more conscious about susceptibility to HBV.

Besides education level, another factor that we predicted based on both multiple models; vaccination and seroprotection, was the use of protective equipment by the HCWs. It was observed that professionals susceptible to HBV that reported "no" for PPE use during work were significantly more susceptible to HBV than those who reported "yes". This result is possibly explained by the fact that workers that take protective attitudes in their clinical practices were more aware about immunization and vaccination $^{30}$. Similar results were found in two other Brazilian states, Minas Gerais and Bahia $^{3,31}$.

Another significant result was observed only for the vaccination model; "personal serological evaluation" was associated with susceptibility to HBV. This is a similar situation to the PPE's results and might reflect the personal attitude to be protected against transmissible diseases by the HCWs. This result should be carefully interpreted because it represents only the self-report, and there is 
possibility of bias (due to the poor agreement between vaccination and seroprotection status). In addition, for the immunization status, this factor was not predictable.

Although no other result was significant in the final multiple model, some important descriptive seroprotection status data should be addressed here. The descriptive information of the absolute number for HBV susceptibility in table 2 shows that most workers are women, single, working more than 10 years and professionals including nursing categories. This descriptive pattern is a reality already verified in the Brazilian context by many other studies, especially considering that many health professionals, mainly those in the nursing areas, are females ${ }^{3,24,26,28,30,31}$. Different pattern for sex distribution was observed in India, based on a study involving $678 \mathrm{HCWs}$ in a Medical College. Limitations related to the date of vaccination should be considered, as we were unable to obtain this type of information, once that many of the professionals did not have the card vaccine at the moment of the interview. It is recognized that the HBV vaccine is more effective in the childhood, however its effectiveness decreases with increasing age.

\section{CONCLUSION}

This study presented a multicenter investigation among healthcare workers of several health unities in the state of Alagoas, located in Northeastern Brazil. We predicted some factors that could be associated with HBV susceptibility; however, we presented the problem in its first situation through a crosssectional perspective, assuming that outcomes and exposures are occurring at the same time in the period. This is the main limitation that we need to interpret when dealing with crosssectional studies. On the other hand, this type of investigation is useful to quickly check the current status of population groups and list important factor for a deeper investigation.

An advantage of our study comparing to other studies is the use of serological test to assess susceptibility to Hepatitis B. Further investigations are needed to better understand the reasons why some health workers still are not fully vaccinated against HBV. Some authors pointed out some barriers for vaccination among HCWs that could a be a key-factor of future investigations such as fear of side effects, no perception of risk infection, few information about transmission, pressure at work, access and cost $^{3}$. One obvious rationality is to vaccine this non-immune health workers, however the best strategy to prevent HBV is the universal vaccination of infants rather than focus on highrisk groups. ${ }^{16}$ It is always important to remember some efforts to reduce exposition to Hepatitis B virus by HCWs such as adoption of correct operation procedures, use of non-sharp instruments whenever possible and increase seroprotection through the vaccination of all health workers.

REFERÊNCIAS

1. Mast EE, Margolis HS, Fiore AE, Brink EW, Goldstein ST, Wang SA. A comprehensive immunization strategy to eliminate transmission of hepatitis B virus infection in the United States: recommendations of the Advisory Committee on Immunization Practices (ACIP) part 1: immunization of infants, children, and adolescents. MMWM Recomm Rep. 2005;54(RR-16):1-31.

2. Morowatishaifabad $M$, Sakhvidi MJ, Gholianavval M, Boroujeni DM, Alavijeh MM. Predictors of hepatitis $B$ preventive behavioral intentions in healthcare workers. Saf Health Work. 2015;6(2):139-42.

3. Assunção AA, Araújo TM, Ribeiro RB, Oliveira SV. Hepatitis $B$ vaccination and occupation exposure in the healthcare sector in Belo Horizonte, Southeastern Brazil. Rev Saude Publica. 2012;46(4):665-73.

4. Brasil. Ministério da Saúde. Secretaria de Vigilância em Saúde. Departamento de DST, Aids e Hepatites Virais. O manual técnico para o diagnóstico das hepatites virais. Brasília: MS 2015. 68p.

5. Department of Health \& Human Services. Centers for Disease Control and Prevention CDC. Division of Viral. Interpretation of hepatitis B serological test results. [cited 2018 Dec 5]. Available from: https://www.cdc.gov/hepatitis/ hbv/hbvfaq.htm.

6. Abebaw TA, Aderaw Z, Gebremichael B. Hepatitis B virus vaccination status and associated factors among health care workers in Shashemene Zonal Town, Shashemene, Ethiopia: a cross sectional study. BMC Res Notes. 2017;6(10):260.

7. Akibu $M$, Nurgi $S$, Tadese $M$, Tsega WD. Attitude and vaccination status of healthcare workers against hepatitis B infection in a teaching hospital, Ethiopia. Scientifica. 2018;ID:6705305. 8p.

8. Batra V, Goswami A, Dadhich S, Kothari D, Bhargava N. Hepatitis B immunization in healthcare workers. Annals of Gastroenterology. 2015;28(2):276-80.

9. World Health Organization. Hepatitis B, Fact sheet No. 204, updated July 2018. Available from: $\quad$ http://www.who.int/mediacentre/ factsheets/fs204/en/.

10.Pereira LM, Martelli CM, Merchán-Hamann E, Montarroyos UR, Braga MC, Lima ML et al. 
Population-Based multicentric survey of Hepatitis $b$ infection and risk factor differences among three regions in Brazil. Am J Trop Med Hyg. 2009;81(2):240-47.

11. Contera-Moreno L, Andrade SM, Cury Pontes ER, Stief AC, Pompilio MA, Motta-Castro AR. Hepatitis B virus infection in a population exposed to occupational hazards: firefighters of a metropolitan region in central Brazil. Rev Soc Bras Med Trop. 2012;45(4):463-67.

12. Petruzziello $A$. Epidemiology of hepatitis $B$ virus (HBV) and hepatitis $\mathrm{C}$ virus (HCV) related hepatocellular carcinoma. Open Virol J. 2018;12(Suppl-1, M3):26-32.

13. Aaron D, Nagu TJ, Rwegasha J, Komba E. Hepatitis B vaccination coverage among healthcare workers at national hospital in Tanzania: how much, who and why? BMC Infect Dis. 2017;17:786.

14. Bonanni $P$, Bonaccorsi G. Vaccination against Hepatitis B in health care workers. Vaccine. 2001;19(17-19):2389-94.

15.Ziglam H, El-Hattab M, Shingheer N, Zorgani A, Elahmer $O$. Hepatitis $B$ vaccination status among healthcare workers in a tertiary care hospital in Tripoli, Libya. J Infect Public Health. 2013;6(4):246-51.

16. Chang $\mathrm{MH}$, Chen DS. Prevention of hepatitis $\mathrm{B}$. Cold Spring Harb Perspect Med. 2015;5:a021493.

17. Divisão de Imunização. Vacina contra hepatite B. Rev Saúde Pública. 2006;40(6):1137-40.

18. Brasil. Ministério da Saúde. Secretaria de Políticas de Saúde. Programa Nacional de Hepatites Virais. Brasília: Ministério da Saúde, 2002. 64p.

19. Marques CC, Carvalheiro JR. Assessment of laboratory diagnostic network in the implementation of the Program for Viral Hepatitis Prevention and Control in São Paulo State, Brazil, 1997-2012. Epidemiol. Serv. Saude. 2017;26(3):513-24.

20. Andrade Neto EP, Dutra CS, Lima V, Goes P. Prevalence of occupational accidents and vaccination profile against hepatitis $B$ between students and dental professionals: a pilot study. Arq Odontol. 2013;49(1):32-8.

21. Oliveira LC, Pontes JP. Frequency of hepatitis B immunity and occupational exposures to body fluids among brazilian medical students at a public university. Rev Inst Med Trop. 2010;52(5):247-51.

22. Instituto Brasileiro de Geografia e Estatística IBGE. IBGE Cidades Alagoas. Available from: https://cidades.ibge.gov.br/brasil/al/panorama.

23. Governo do Estado de Alagoas. Secretaria de Estado da Saúde - Sesau. Unidades e Serviços. Available from: http://www.saude.al. gov.br/acesso-a-informacao/130-2/.
24. Garcia LP, Facchini LA. Hepatitis B vaccination among primary healthcare workers. Cad Saúde Pública. 2008;24(5):1130-140.

25. Stroffolini T, Petrosillo N, Ippolito G, Lopalco A, Sagliocca L, Adamo B. Hepatitis B vaccination coverage among healthcare workers in Italy. Infect Control Hosp Epidemiol. 1998;19(10): 789-91.

26. Costa FM, Lima Martins AM, Santos Neto PE, Veloso DN, Magalhães VS, Ferreira RC. Is vaccination against hepatitis $B$ a reality among primary health care workers? Rev Latino-Am Enfermagem. 2013;21(1):316-24.

27. Burmett RJ, François $G$, Mphahlele $M J$, Mureithi JG, Africa PN, Satekge MM, et al. Hepatitis $B$ vaccination coverage in healthcare workers in Gauteng Province, South Africa. Vaccine. 2011;29(25):4293-97.

28. Rossato EM, Ferreira J. Perforating injuries and vaccination against hepatitis $B$ among health workers in the Municipality of Santa Rosa, State of Rio Grande do Sul, Brazil, 2008.

29. Brasil. Ministério da Saúde. Secretaria de Vigilância em Saúde. Programa Nacional de Imunizações. Coberturas vacinais no Brasil período: 2010 - 2014. Brasília: Ministério da Saúde, 2015. 31p.

30. Souza FO, Freitas PS, Araújo TM, Gomes MR. Hepatitis B and Anti-HBS vaccination among health workers. Cad Saúde Colet. 2015;23(2): 172-79.

31. Souza FO, Araújo TM. Occupational exposure and hepatitis $B$ vaccination among health care workers. Rev Bras Med Trab. 2018;16(1):36-43.

\section{CONFLICTS OF INTERESTS}

The authors declare no conflicts of interests.

\section{CORRESPONDING AUTHOR}

\section{Dr. Kevan Guilherme Nóbrega Barbosa}

Centro Universitário Cesmac, Campus IV, Rua Prof. Ângelo Neto, 51, Farol, Maceió - AL, Postal code: 57051-530; Phone: +55 (82) 3215-5000

E-mail: kevanguilherme@gmail.com 